IPRA Code of Athens - the first international code of public relations ethics: Its development and implementation since 1965

\author{
Tom Watson PhD \\ Professor of Public Relations \\ The Media School \\ Bournemouth University \\ Poole, Dorset BH12 5BB, UK \\ Email: twatson@bournemouth.ac.uk
}




\section{IPRA Code of Athens - the first international code of public relations ethics: Its development and implementation since 1965}

\section{Introduction}

At Athens, Greece on May 12, 1965, the International Public Relations Association adopted a draft of an International Code of Ethics for public relations practice. The Code had been an object of the nascent IPRA since 1952 and was to become a major promotional strategy of the organisation from the mid-1960s onwards. Largely written by the French public relations leader Lucien Matrat (IPRA 2001), it followed an earlier IPRA Code of Conduct (known as the Code of Venice) and was adopted wholly or in a modified form by many public relations professional associations in subsequent years (IPRA, 1994).

In this paper, which is based mostly on material from the IPRA archive held at Bournemouth University (Watson, 2011), the formation and implementation of the Code of Athens is traced from the early 1950s until the mid-2000s. It discusses IPRA's external presentation of the Code as well as the internal debate between leading members about its relevance and implementation, which led to major revision just three years after it was adopted. Reviewing the emphasis on the Code’s dissemination by its main author, Lucien Matrat, the paper will also consider whether it became a publicity strategy of IPRA and not the proposed standard for ethics in public relations sought by its founders. IPRA's subsequent employment of the Code was mainly symbolic and instrumental. There will also be consideration of the role of ethical codes and whether they can be 'universal' across all cultures, religions and ethical 
backgrounds, as IPRA sought. This will, it is hoped, advise current ethical discussions in public relations in what some consider as the post-professional era (Fawkes, 2012).

\section{Ethical codes}

Most public relations professional bodies and trade associations have some form of ethical and/or practice rule or code (Seib \& Fitzpatrick, 1995; Fitzpatrick \& Bronstein, 2006). Typical examples are of the Chartered Institute of Public Relations (CIPR) and the Public Relations Consultants Association (PRCA) in the United Kingdom. CIPR has a four-section document including a Code of Conduct (CIPR, undated); while PRCA has a Professional Charter for all members plus specialist versions for public affairs and healthcare. Both have complaints and arbitration procedures. The PRCA code commences with a general exhortation for members:

A member shall:

1.1 Have a positive duty to observe the highest standards in the practice of public relations. Furthermore a member has the responsibility at all times to deal fairly and honestly with fellow members and professionals, the public relations profession, other professionals, suppliers, intermediaries, the media of communication, colleagues, and above all, the public. (PRCA, undated, p. 1)

Bowen (2007) comments that in public relations, "ethics includes values such as honesty, openness, fair-mindedness, respect, integrity, and forthright communication” (p.1). These values appear to be widely applied around the world. Many codes also have a "best interests of the profession” element, for example the Public Relations Society of America (PRSA). Wright (2006), a long-time prominent IPRA member and a leading US public relations academic, acknowledges the Code of Athens' obligation for respect of human rights including those related to "intellectual, moral and social needs" (p. 189). He also introduces the moral core which separates it from typical codes of conduct for practitioners: 
The code recognizes the power of public relations in the global society, noting the need for ethical conduct by public relations professionals who have the ability to reach and potentially influence millions of people. Such power must be restrained, according to the code, "by observance of a strict moral code” (ibid, p.189).

In the history of the Code of Athens’ development and implementation which follows, the insertion of a human rights-focused moral core for this ethical code will be seen as an unintended consequence of the IPRA's founders' desire to establish such a code. Other elements of this code and the Code of Conduct (the "Code of Venice” adopted in 1961) were similar to other professional codes of their time and have significantly influenced current codes, as indicated by Bowen (2007) and Wright (2006).

\section{Evolution of codes}

Although IPRA was not formally established until 1955, discussions in Europe about its formation had begun in 1949. Among its draft 'Objects' agreed in 1952 was a code of ethics on an international scale. Minutes from 1953 reported on the previous year's discussions made this clear:

(i) Aims and objectives

That an International Association should have as its aims

a) The raising of the standards of Public Relations practice in all countries

c) Explaining public relations to the world outside the profession

e) Consideration of the problems facing public relations officers in all countries ... professional ethics (linking the codes now being compiled in several countries) (London \& Hastings Minutes, 1953, p. 3)

It can be seen that preparation of a code of ethics was a priority. This was reinforced in 1955 when IPRA was established at a meeting in London on April 29, 1955: a modified version of the 1952 decision was adopted as an 'Object for the Association': 
e) To review and seek solutions to problems affecting public relations practice common to various countries, including such questions as the status of the profession, codes of professional ethics and qualifications to practice (London Minutes, 1955, p. 4).

At its second Council meeting in The Hague, Holland, later that year, a French member Etienne Bloch was commissioned to undertake research into "professional ethics, status and qualifications” (Hague Minutes, 1955, p. 3) and prepare a report. This was presented to the Council's next meeting in Paris the following year and IPRA decided to move forward:

It was generally agreed that the Association should move towards a position where it could advise its members of the professional standards expected of them (Minutes underlining), and that work should continue towards this end after the Council members had had an opportunity of studying the subject in the light of local conditions in their various countries (Paris Minutes, 1956, p.6).

(Bloch's reports are not in the IPRA archives). A leading US practitioner Robert L. Bliss

was the chair of the IPRA Research Committee at the time. In a later memoir he reported that the Code of Ethics was a very high priority goal for the new association but it was developed as a Code of Conduct. The Code of Ethics came later, as he explained.

Goal 1: To develop and propose a Code of Ethics. There was some question over the use of the word 'Ethics' at such an early stage in IPRA's development, so the name was changed to 'Conduct'. The 10-member international committee worked diligently for four years on the Code which was reviewed and accepted by the Board at the Second World Public Relations Congress in Venice in 1961 (Bliss, 1984, p.41).

Conversely, one IPRA founder, Tim Traverse-Healy has claimed latterly that ethics were not an early priority:

Looking back I now believe that the apparent indifference they displayed to the matter of ethics in our craft was dictated by their profound belief that the very practice of public relations as they envisaged was in itself, in the fractured and tortured world of the time, an ethical act needing no explanations or defence (Traverse-Healy, 2007, p. 12)

The founders' collective view, he has written, was that public relations comprised three elements - truth, concern for the public and genuine dialogue. "By current reckoning we would 
appear a bunch of purists” (ibid, p. 13). However, the weight of bureaucratic and other evidence challenges his interpretation, but IPRA's subsequent development of its Code of Ethics demonstrates that although there may have been written priority it was not a focus of broad discussion and concentrated effort.

\section{The Code of Venice}

The Code of Professional Conduct was adopted with minor amendments at the Council meeting in Venice on May 22, 1961 (Venice Minutes, 1961) and was agreed by the IPRA Assembly and $2^{\text {nd }}$ IPRA World Congress (IPRA, 1994) the following day. It quickly became known as ‘The Code of Venice’ (IPRA, 1961, 2009)

The Code of Conduct, occasionally contemporaneously referred to a code of ethics (Paris Minutes, 1962), set out standards of conduct towards employers and clients, the public and media, and towards colleagues. There were calls for fair dealing, honesty, respect for confidential matters, public interest and practitioner reputation. It also forbade acceptance of bribes, and the undermining of a fellow practitioner's relationship with an employer or clients. In 1962, IPRA formed a Professional Practices Committee "to enforce respect for the Code of Conduct" and decided that the "Code of Conduct should be included in the application form and signed by all new members joining up” (Paris Minutes, 1962, pp. 13-14). This Committee continued into the mid-1970s.

\section{The Code of Athens}

The decision to create a Code of Ethics is not recorded in the extant IPRA archive. There are, however, two narratives which were later compressed into one story of IPRA's commitment to a higher standard of ethics in its content and organisational aspirations. There was no mention 
of plans for a Code of Ethics in Minutes of IPRA Council meetings, until it was launched by Lucien Matrat at the Montreal Council meeting in November 1964.

Matrat's and IPRA's narratives tell of the formation of a working group, led by him, meeting throughout 1964. Its members included the current IPRA president John Keyser and a past-President Denys Brook-Hart, five French practitioners and a French and a Belgian academic. A more recent IPRA document claims, quite erroneously, that it was joint effort involving senior office-holders and academics:

The original draft of the Code was prepared with the help of the 1963-65 IPRA President John A. Keyser, IPRA Secretary Manos Pavlidis, CERP Chairman Guido Rossi del Lion Nero and Philippe Hurteau and Vincent Levaux, both representing the university teachers. It based on the United Nations "Universal Declaration of Human Rights” and was adopted unanimously by the IPRA General Assembly in Athens, Greece May 1965 (IPRA, 2001, p.6).

IPRA's records of the formation of the Code of Athens do not support this presentation.

For example, Guido Rossi del Lion Nero is not mentioned in Matrat's records (Matrat correspondence, 1964) and it was not adopted unanimously at the Athens meeting, but provisionally accepted. Adoption came later the same year. IPRA's $40^{\text {th }}$ anniversary history publication (IPRA 1994) claims that the association had been a full party to the draft code presented by Matrat to the IPRA-organised World Public Relations Conference in Montreal, Canada in November 1964 and that it has been presented by a past-President, Denys Brook-Hart. Minutes, however, clearly demonstrate that it had been a surprise to the IPRA Council which had not seen it before:

The President informed the Council that Mr. Lucien Matrat has produced a paper for the World Congress on "Ethics and Conduct". His proposal was to establish an international code of ethics. In his paper he emphasized the difference between a code of conduct and a code of ethics. Mr Keyser [then IPRA President] felt that this was an important matter and both he and Mr de la Motte [French Council member] hoped that IPRA would take cognisance of this proposal before the World Congress. He recommended that this paper 
should be read by members and discussed at the Athens meeting ... Copies of the paper will be made available to members of the Council (Montreal Minutes, 1964, p. 16).

This shows that John Keyser, who was named by Matrat and IPRA’s histories (IPRA 1994, 2001) as an integral member of the team which prepared the Code of Ethics, had doubts about its rapid adoption. In Athens, he again expressed caution but voted for adoption. IPRA's later narrative was that there was "wide consultation prior to its (Code of Ethics) unanimous adoption by the General Assembly at Athens on 12 May 1965” (IPRA, 1994, p. 92). This was highly inaccurate as the IPRA Council preceding the General Assembly had grave doubts about its adoption without consulting the membership.

Mr Pavlidis [IPRA Hon Secretary] spoke in favour of the adoption of the proposed Code of Ethics as it would raise the status of the public relations. Mr Keyser pointed out that the regular members of IPRA had not had the opportunity to study the proposed Code but could not see why Council should not accept it. Milton Fairman asked if there was a copy in English (Athens Minutes, 1965, p. 4).

(Fairman’s comment was appropriate as Matrat operated solely in French and presented papers to IPRA only in his native language). Other Council members argued that it should not be mandatory on members; that Council could not accept it before members had seen it. It was decided that the Council would accept the draft Code but that members would be sent the draft. "It was agreed to call this Code the Code of Athens" (Athens Minutes, 1965, p. 4). The Council would later adopt the Code of Ethics but in mid-1965, it was as unknown to IPRA Councillors as it was to the general membership.

Before discussing the dissemination and implementation of the Code of Athens, it is germane to consider the attitudes and influence of Lucien Matrat, a major figure of western European public relations over a 30-year period but who has little recognition elsewhere. Matrat was considered to be the "father of public relations in France" (Boiry, 1989, cited in Xifra, 2012) and became a dominant figure in the French-speaking world and in Spain forming a "European 
doctrine of public relations” in the early 1970s. A public relations manager for the French-owned Elf petroleum group throughout his career, he considered PR methods used by American oil companies were propagandist and "lacking respect for individuals. He therefore became interested in the ethical nature of public relations and its distinction from propaganda and advertising” (Xifra 2012, p. 565). His enduring international influence is the Code of Athens, which Xifra argues, "is another example of the anthropology of public relations founded by Matrat” (2012, p. 569).

Matrat, he adds, "acted as an anthropologist of the moral” (ibid) with an example being his 1975 statement that "without ethical practice, public relations has no purpose” (Matrat, 1975, cited in Xifra, 2012, p. 569). For the IPRA leadership in 1965, the humanist philosophical content of Matrat's approach to ethics was probably subordinated to their appreciation that he was a willing and influential volunteer who prepared a Code of Ethics. Tim Traverse-Healy acknowledged this pragmatic aspect in a 2011 interview:

We were an idealistic lot and I think we were setting the concept of the idea of public relations and could see that reflected in the code of ethics as produced by Lucien Matrat...We felt it would help define public relations internationally...IPRA could use it by having it documented (and) codified...and Lucien Matrat picked up the baton and worked extremely hard (Traverse-Healy, 2011, p. 9).

The code proposed by Matrat, in French, was based on the UN Declaration of Human Rights of 1948. He proposed it as a universal code of ethics for public relations and an important differentiator of public relations from what he considered lesser forms of communication such as advertising and promotional propaganda. The philosophy of public relations, as noted above, was an important anthropological concept for him:

Mr Matrat explained the need for such a Code and said that by such a Code we were proposing to enter into the dialogue of civilisation. That dialogue requires the respect of the moral rights of man as an individual (Athens Minutes, 1965, p.3). 
He argued the mantra that public relations was a higher calling and later, in 1969, told an IPRA meeting in Dublin that "true ethics are not just to be a moral background, but also a mode of professional and everyday life, underlining the role of PR as a continuous effort towards the acceptance of sincere and sound human relations” (Dublin Minutes, 1969, p. 6). In 1978, he continued to promote his case for the Code as it "both differentiates public relations from merely a type of sociological propaganda, and becomes, because of its principles, a fundamental code of behaviour” (Matrat, 1978, p. 15).

Matrat's case for a code of ethics in addition to a code of conduct or practice was made many times within IPRA. It is captured in IPRA's $40^{\text {th }}$ anniversary history which expresses the Matrat paradigm:

...national codes of professional conduct must take into account the laws, usages and customs in force in each country and the prevailing circumstances. An ethical code, however, prescribes the behaviour of public relations practitioners in relation to people, considered as 'human beings'. Since the nature of the human being is universal, there can only be one ethical code (IPRA, 1994, p. 92).

This was consistent with his promotion of the ethical canon as being universal and thus above the pragmatic behaviours of practitioners and their work relationships. Its conception as a complete set of strictures, however, fell foul of Anglo-American practitioners who held different views of human behaviour. The Code that Matrat produced comprised a contextual introduction linked to the UN Declaration of Human Rights. This is followed by 13 elements or rules.

The introduction explains the fundamental rights and dignity of all human and states that public relations practitioners "can substantially help to meet these intellectual, moral and social needs” (IPRA 2001, p.6). The use of techniques that permit communication with millions of people gives practitioners "a power to be restrained by the observance of a strict moral code" (ibid, p. 6). In three clusters, these call for (1) practitioners to aid fellow humans to achieve their 
full stature and rights; to foster free flow of information; to conduct themselves in a manner that gives confidence to others; and to consider their public-professional and private behaviour as having an effect on the profession's reputation; 2) to observe the Declaration of Human Rights; have regard to the dignity of others; establish moral conditions for true dialogue for all parties; act in the best interests of all parties - organisation and publics; act personally to avoid misunderstanding and with integrity to all parties; and (3) be truthful, circulate information based on ascertainable fact; not take part in any activity affecting human dignity and integrity; and not use any manipulative methods (IPRA, 2001).

Elements calling for truthful and non-manipulative communication, behaviour that builds confidence in others, and recognition of the integrity of others are common in codes. The Code of Athens's link to the Declaration of Human Rights and claims upon personal behaviour, however, proved difficult for some members. For example, the first and fourth rules were that members:

Shall (initially Must) Endeavour

- To contribute to the achievement of the moral and cultural conditions enabling human beings to reach their full stature and enjoy the indefeasible rights to which they are entitled under the Universal Declaration of Human Rights;

- To bear in mind that because of the relationship between his/her profession and the public, his/her conduct - even in private - (author's emphasis) will have an impact on the way in which the profession as a whole is appraised (IPRA, 2001, p. 7).

The potential scope of the Code was thus immense for IPRA members, as it ranged from a general responsibility for humanity's rights to the specifics of their personal behaviour. As the critical response to the Code shows in the next section, IPRA had slept-walked into a morally- 
intense code which was not implementable. Rather than amend or repent, it chose to use it as a promotional tool.

\section{Criticism and revision}

After the Code had been adopted in 1965 and endorsed at the Barcelona meeting in 1966 (Barcelona Minutes, 1966), there was continued debate about its relevance to public relations practice. The critique was led by the UK's Alan Eden-Green, Chief Executive - Public Relations of the British Oxygen Company (BOC). The Code was again debated at the IPRA Council in Rio de Janeiro in 1967 (Rio Minutes, 1967), after which Eden-Green wrote to Matrat, who had not attended. He contended that the Code placed many IPRA members automatically in breach of its rules, and also restricted their human rights to take employment as they wished. The tone of Eden-Green's comments is very terse and indicated the problems of creating universal ethical codes which do not account for cultural/social understandings or effective implementation:

...the sections I quoted place a moral obligation to raise a protest when we see human liberty or dignity being threatened, but they certainly would prevent any IPRA member from working for a government which does not uphold Human Rights. The Code, in fact, is not a set of guide-lines, but a set of rules. It says "must" and "must not". I doubt whether that was your intention but, as you know, I have always had the misgiving that it was too rigid and put us in the position of being committed to a set of standards we could not live up to (Eden-Green correspondence, 17 October 1967).

Eden-Green continued, making a case for a more pragmatic approach:

I believe - and so do many of my British colleagues - that such Codes are highly desirable, but only provided they will stand the test of examination. At the moment we most certainly have members working for governments which, it could be said, restrict basic human rights...I personally believe the Code should be regarded only as an ideal and that it is not practicable to restrict our members in the way the Code appears to do (Eden-Green correspondence, 17 October 1967).

Eden-Green concluded by offering his support for the Code with "acceptable wording"

and asked for Matrat to send him six copies of the Code in English. Matrat replied in early 
November 1967 defending his approach and citing the endorsement of religious leaders, including Pope Paul VI, as justification for it. He also proposed that IPRA could invoke the Code against a country which was restricting human rights or controlling its media (Matrat correspondence, November 1967).

Eden-Green was not mollified by Matrat's response, but commented that "there is no great difference of opinion between us” (Eden-Green correspondence, 24 November 1967). His concerns remained with the Code's wording and not its aims or content. In response to Matrat's case that the Code had social and religious support, Eden-Green retorted with:

It has not (writer's emphasis) been praised by any high religious or political authorities in this country. The latter, I am sure, would immediately say: "This is fine - Do you enforce it?" To which we would have to say: "No".

You see, the Code is not worded as if it were an ideal to aim at. It says, quite specifically, that a person must "Respect and uphold the dignity of the human person ..." etc. "and must undertake not to lend his assistance to ..." (Eden-Green correspondence, 24 November 1967).

Eden-Green argued later in the letter that IPRA members must be allowed to act according to their conscience. He warned that IPRA was in danger of over-promoting the Code. "Public Relations has suffered a great deal here (the UK) and in the USA because it has sometimes made claims that it could not honour” (ibid). There were misgivings about the Code from other Council members in Rio and some amendments were needed to allay their fears and made the Code. "If we do not do this, we remain very vulnerable to public criticism" (ibid).

Eden-Green had continued doubts about the Code: "Personally I would like to see the Code completely redrafted” (ibid, 8 April, 1968). He offered minor but textually important changes such as replacing "Shall Undertake” with "Shall Endeavour" in clauses 5-9. These moved the emphasis from obligation to best effort. Eden-Green's central point was that the Code 
“imposes a condition which I do not think we can always demand of our members” (Eden-Green Correspondence, 8 April 1968). At IPRA’s Tehran meeting in 1968, his amendments were accepted (Tehran Minutes, 1968).

\section{Code as a PR strategy}

Using a five-step strategy promoted by Matrat, IPRA had gained support from many national public relations bodies and had staged photo-based presentation events that involved Pope Paul VI, the presidents of India and the Council of Europe and various heads of state and government ministers, as evidenced by numerous photographs in the IPRA archive (Watson, 2011). While these gave 'name check' value to the Code and promoted its acceptance in the public relations sector, Matrat's strategy was more pragmatic in its desired outcomes than he had promoted earlier.

In March 1967, he had circulated a strategy document with the portentous title of 'Procedure recommended for the using the Code of Athens for the purpose of reaching a wider audience and obtaining prestige for our profession' (Matrat, 1967). Seeking 'prestige' for public relations had not been one of the Code’s 13 rules, but the Frenchman wanted the Code to demonstrate that "public relations (is) a guide to social behaviour and as a science of communications" (ibid, p. 1). It was also "the only way to differentiate public relations from a certain type of sociological propaganda” (ibid, p. 2).

IPRA’s history has a section entitled 'Enforcement of the Ethical Code’ (IPRA, 1994, p. 92). However, from 1965 to 2002 (the last date of material in the archive), there are no archival references to any IPRA member being either reported for a breach of either Code or being disciplined. This apparent anomaly has been raised by this author with four past Presidents and 
Secretaries whose IPRA corporate memories range from 1965 to 2002 (and beyond). None recalled any member being disciplined under the Codes of Venice or Athens. For an organisation which was based on personal membership, this was an extraordinarily exemplary disciplinary performance across 37 years. Perhaps Matrat's prestige-building strategy delivered results but it can be contended that for all its lofty attributes, there is little evidence that the Code of Athens helped police public relations’ moral behaviour.

\section{Implementation}

IPRA did little to implement and develop the Code of Athens. As early as 1973 Herbert Lloyd, Matrat's successor on IPRA's Professional Standards Committee, showed ambivalence to it. In IPRA's first Gold Paper, a report of a survey of the adoption of ethical codes and standards by PR associations, Lloyd diminished the importance of IPRA's universal codes, commenting: "With the rapid increase in efficient, almost instantaneous world communications, the need for a common acceptable code becomes even more pressing” (Lloyd, 1973, Introduction).

Of 26 countries which responded to the survey, 82\% had adopted a Code of Ethics. "In most cases they have taken the Code of Athens as it stands, or as a model with some local variation" (ibid, p.7). Among the Gold Paper’s recommendations was that "Recognition of an adequate code by every practitioner should be encouraged throughout the world” (p. 11). This could be interpreted in two ways - the adoption of a universal code or that every nation had a code with similar factors. But the Code of Athens was not proposed by Lloyd as the solution.

Goran Sjoberg, a former IPRA president, has noted that ethics were discussed in five Gold Papers, Nos 1, 5, 6, 8 and 10 (Sjoberg 2007). Only Gold Paper 10 supported Code of 
Athens, narrowly in relation to client confidentiality. Most of these discussions did not relate to this Code, its implementation or development over time.

In Gold Paper No.8, Ethical dilemmas in public relations: A pragmatic examination, US

practitioner John F. Budd did not refer to either Code and belittled their role:

Ethical rules do not resolve ethical dilemmas nor create ethical practitioners. Codes are verbal (sic) resolutions of ethical dilemmas but by and of themselves will no more reform an unethical practitioner than thieves will be reformed by reading criminal statutes. Nor will laws (sanctions, et al) discourage the bending of rules ... Our codes, now in place transnationally, are no panacea (Budd, 1991, p 2).

Budd added that "in the United States alone these codes are often wantonly honored in the breach" (ibid, p.4). These comments, in the highest level IPRA publication, showed a lack of organisational belief in either the Code of Athens or the concept of universal codes.

A decade and a half later, Tim Traverse-Healy posited that the Code of Athens "is the closest to a formulation of moral philosophy upon which the profession of public relations is based” (Traverse-Healy, 2007, p.14). It was, he claimed, supported by most national public relations professional bodies. However, the IPRA founder admitted its universal codes had lost support:

It must be recorded that in the four decades since its inception most of the codes constructed by these national associations, albeit influenced by the examples of the original leaders, the United States, Canada and the United Kingdom, have adopted a distinctly different emphasis... (and are) focused on occupational and commercial concerns such as practitioner relationships with employers, employees, clients, intermediaries and peers (Traverse-Healy, 2007, 14-15)

\section{Discussion and conclusions}

The Code of Athens continued in its 1968 modified form until 2011 when it was merged with other IPRA codes into a single 18-point code (IPRA, 2011). In one way, it had passed a test 
of endurance. Although extensively referred to, there is little evidence that it was more than a promotional tool for IPRA, as its photo archive of presentations demonstrates. IPRA, as noted above, does not appear to have invoked the Code against a member. Its membership, which peaked at little more than 1000 in 1980s, was obviously not attracted by the moral stance, although this may have been less important to them as many national PR bodies had already established codes of conduct by the early 1970s (Lloyd, 1973).

Budd, in Gold Paper No. 8, touched on the central problem of reliance upon ethical codes in his analogies about people with weak moral compasses taking little notice of them; for example that thieves are unlikely to be reformed by reading about criminal laws. Putting aside the argument by Traverse-Healy (2007) and others that many who claim to be public relations practitioners are outside the jurisdiction of professional and industry bodies, the Code of Athens showed universal codes are mainly symbolic. Without promulgation and enforcement, they cannot serve a higher purpose. Even though they are voluntary (Wright, 2006), codes are a benchmarking device or a statement of a profession's or practice’s claimed moral boundaries. They cannot dictate behaviour of individuals, although they can seek to influence them. Codes are also difficult to implement because of competing legal rights, such as defamation and freedom to earn a living (Traverse-Healy, 2007) and are often uneven and infrequent in their enforcement (Wright, 2006). It is, however, inconceivable that PR bodies would dispense with them because of the ensuing reputational damage.

However, the greater threat to these ethical stances may come from the challenge to the professional model itself. Fawkes (2012) has commented that "traditionally professions secured (or at least asserted) public trust by virtue of their professional status (body of knowledge, extensive training, extra-moral ethical standards)" (p. 119). She argues the concept of 
professionalism is under severe threat and professional identity is in crisis. Professional bodies are bureaucratic mechanisms to promote exclusivity and monopolistic practices. In the case of public relations, which has never had boundaries to entry (other than in regulated Brazil), new approaches to the promotion of ethical behaviour may be needed which focus on the individual rather than the organisation. As Budd (1991) and Traverse-Healy (2007) asserted, individuals each have moral compasses. Future debate, education and training may need to focus on aiding the individual's “everyday ethical decision-making” (Parsons, 2004, xvi) rather than bolstering the quasi-professional nature of industry bodies.

In contrast, the European Communication Monitor 2012 (Zerfass et al, 2012) reported that $77 \%$ of respondents found management of ethical issues was more important than five years ago, but only $29 \%$ have ever applied a public relations code of conduct in their daily work. (The example of the Code of Athens was quoted). "An explanation for the poor utilisation of overarching professional norms might be found in the low acceptance of the current codes. Almost 32\% of the professionals think that typical ethical codes provided by the PR associations are outdated" (ibid, p. 19). In contrast to Fawkes (2012), this large sample (2295 completed the survey) showed faith in national and international PR organisations to provide updated guidance on ethical issues. "An overwhelming majority of $93 \%$ finds that the communication profession needs such rules" and ECM 2012 says this "can be interpreted as a call to action to provide upto-date guidelines made to fit the digital age across Europe” (ibid, p19).

Further research is needed into both the personal post-professional model of public relations and the type of guidance on ethical issues sought by the ECM samples, which was drawn from 42 countries. The existing models, as shown by the Code of Athens and many 
national codes are outdated. New thinking is needed on the purpose of future guidance, whether in a code or as learning, and its implementation.

For modern codes of practice and their successors, the IPRA example has practical lessons worth considering; principally that a professional organisation should not walk blindly into adoption of such statements. Matrat, with his belief in humanist ethical principles and considerable guile, took on a task while the organisation dithered from 1962 to 1964 and delivered a solution which was adopted on behalf of members. In the borderless digital age, there must be a ground-up approach to ethics in order that there is wide acceptance of future codes and rules, and the ability to implement them. IPRA was forced to retain an ethical code which it was never to invoke. The outcome was that it became a promotional tool - a classic "PR exercise", as Matrat later commented (Matrat, 1978). 


\section{References}

Bliss, R. L. (1984). IPRA: The first 15 years. IPRA Review, 8(3), 40-41.

Boiry, P. A. (1989). Les relations-publiques ou la stratégie de la confiance. Paris: Eyrolles.

Bowen, S. (2007). Ethics and public relations. Gainesville, FL: Institute for Public Relations. Retrieved from: http://instituteforpr.org/topics/ethics-and-public-relations/.

Budd, J. F. (1991). Gold Paper No.8 - Ethical dilemmas in public relations: A pragmatic examination. Geneva: International Public Relations Association.

CIPR (undated) - Chartered Institute of Public Relations Code of Conduct and Complaints Procedure. London: CIPR. Retrieved from: http://www.cipr.co.uk/sites/default/files/CIPR\%20Code\%20of\%20Conduct.pdf.

Eden-Green, A. (1967-68). Correspondence on Code of Athens. IPRA Archive: Code of Athens.

Fawkes, J. (2012). Interpreting ethics, public relations and strong hermeneutics. Public Relations Inquiry, 2012, 1 (2), 117-140.

Fitzpatrick, K., \& Bronstein, C., (eds) (2006). Ethics in public relations: Responsible advocacy. Thousand Oaks, CA: Sage.

IPRA (1953). Provisional Committee for the Establishment of an International Public Relations Association - Minutes of Meetings, London, May 8, and Hastings, May 9, 1953.

IPRA (1955). Provisional Committee for the Establishment on an International Public Relations Association - Minutes of Meeting, London, April 29, 1955.

IPRA (1955). Minutes of the Second meeting of the Council of the International P.R. Association, The Hague, Holland, 14 October, 1955.

IPRA (1956). Minutes of the Third meeting of the Council of the International Public Relations Association, Paris, France, May 31-June 2, 1956.

IPRA (1961). Minutes of the Eighth meeting of the Council of the International Public Relations Association, Venice, Italy, May 22, 1961.

IPRA International Public Relations Association (1961, 2009). Code of Venice. IPRA. Retrieved from: http://ipra.org/images/Code\%20of\%20Venice.pdf.

IPRA (1962). Minutes of the Tenth meeting of the Council of the International Public Relations Association, Paris, France, May 8, 1962. 
IPRA (1963). Minutes of the 12th meeting of the Council of the International Public Relations Association, Berlin, Germany, May 28-29, 1963.

IPRA (1964). Minutes of the $16^{\text {th }}$ meeting of the Council of the International Public Relations Association, Montreal, Canada, November 8, 1964.

IPRA (1965). Minutes of the $17^{\text {th }}$ meeting of the Council of the International Public Relations Association, Athens, Greece, May 12, 1965.

IPRA (1966). Minutes of the 19th and 20th meetings of the Council of the International Public Relations Association, Barcelona, Spain, May 23-24, 1966.

IPRA (1967). Minutes of the $21^{\text {st }}$ meeting of the Council of the International Public Relations Association, Rio de Janeiro, Brazil, October 9-10, 1967.

IPRA (1968). Minutes of the 22nd Meeting of the Council of the International Public Relations Association, Tehran, Iran, April 16-17, 1968.

IPRA (1969). Minutes of the 23rd meeting of the Council of the International Public Relations Association, Dublin, Ireland, April 28-29, 1969.

IPRA International Public Relations Association (1994). A commitment to excellence. Sweden: GormanGruppen.

IPRA International Public Relations Association (2001). IPRA codes and declarations. Esher, UK: IPRA, 6-7.

IPRA International Public Relations Association (2011). Code of conduct. IPRA. Retrieved from: http://ipra.org/secciones.php?sec=1\&subsec=3

Lloyd, H. M. (1973). Gold Paper No. 1 - Standards and ethics of public relations practice. (No city): International Public Relations Association.

Matrat, L. (1964-68). Correspondence on the Code of Athens. IPRA Archive: Code of Athens.

Matrat, L. (1967). Procedure recommended for the using the Code of Athens for the purpose of reaching a wider audience and obtaining prestige for our profession. IPRA Archive: Code of Athens.

Matrat, L. (1975). Doctrine européenne des relations publiques, condition du dialogue et de la participation. Estudios de Comunicación Social y Relaciones Públicas, 1, 29-33.

Matrat, L. (1978). The Code of Athens: A recommended procedure for reaching a wider audience and obtaining increased prestige for our profession. IPRA Newsletter, 22(3), 15-17. 
Parsons, P. (2004). Ethics in public relations: a guide to best practice. London: Kogan Page.

PRCA - Public Relations Consultants Association, (undated). PRCA Professional Charter, Public Affairs Code of Conduct, Healthcare Public Relations Code of Practice, Arbitration and Disciplinary Procedures. London: PRCA. Retrieved from: http://www.prca.org.uk/assets/files/AboutUs/Files/PRCA_Codes_of_conduct_and_Profes sional_charter.pdf.

Seib, P., \& Fitzpatrick, K. (1995). Public relations ethics. Fort Worth, TX: Harcourt Brace.

Sjoberg, G. (2007). Ethics in IPRA through 50 years. In: McDowell, J. (Ed). Gold Paper No.16 Ethics in public relations. London: International Public Relations Association, 6-9.

Traverse-Healy, T. (2007). Ethics in public relations. In: McDowell, J. (Ed). Gold Paper No.16 Ethics in public relations. London: International Public Relations Association, 11-22.

Traverse-Healy, T. (2011). Interview with Professor Tom Watson, 21 September 2011. Retrieved from: http://microsites.bournemouth.ac.uk/historyofpr/resources/.

Watson, T. (2011). Archive of the International Public Relations Association. Bournemouth: Bournemouth University. Retrieved from: http://microsites.bournemouth.ac.uk/historyofpr/files/2011/11/IPRA-ARCHIVE.pdf .

Wright, D. W. (2006). Advocacy across borders. In: Fitzpatrick, K., \& Bronstein, C. (Eds), Ethics in public relations: Responsible advocacy, pp. 171-190. Thousand Oaks, CA: Sage.

Xifra, J. (2012). Public relations anthropologies: French theory, anthropology of morality and ethnographic practices. Public Relations Review, 38, 565-573.

Zerfass, A., Vercic, D., Verhoeven, P., Moreno, A., \& Tench, R. (2012). European Communication Monitor 2012. Challenges and competencies for strategic communication. Results of an empirical survey in 42 countries. Brussels: EACD/EUPRERA. 